BIBLIOTECA

JORGE D. WLLIAMS

\title{
JOURNAL OF HERPETOLOGY
}

\section{The Patagonian Telmatobiid Fauna of the Volcanic Somuncura Plateau of Argentina}

\author{
J. M. Cei \\ Institu to Biologia Animal \\ Universidad Nacional de Cuyo \\ Mendoza, Argentina
}

\begin{abstract}
The Late Tertiary basaltic rocks of the Patagonian Meseta of Somuncura, Rio Negro, Argentina, extend for about 15,000 square $\mathrm{km}$ north of $42^{\circ}$ South Latitude, approximately 60 miles from the Atlantic coast. It is a flat stepparian landscape of some $1200-1400 \mathrm{~m}$ elevation in which many temporary clay-lagoons are scattered. Small rocky streams filter from the basaltic uplands towards the lower slopes of the Meseta, about 700-500 m. The fauna of such an isolated environment is very peculiar and a high rate of endemic forms can be emphasized. Two new species of telmatobiid frogs are reported: Telmatobius reverberii from the clay-lagoons of the stepparian uplands, and Telmatobius somuncurensis from the lower rocky streams. Adults and tadpoles of Telmatobius reverberii are described; this form has morphological and ecological affinities with the smaller Telmatobius praebasalticus of the volcanic lagoons of Neuquen, near the Southern Argentine Cordilleras. Certain characteristics of Telmatobius somuncurensis are discussed, such as the uncommon everted cloaca and the similarity between the upper and lower rounded structures of its iris and the upper "meniscus" of the iris of the east-Brazilian Cyclorhamphus. Probable biogeographic relationships and a tentative evolutionary history of these ancient leptodactylid stocks are discussed.
\end{abstract}

\section{INTRODUCTION}

The Meseta of Somuncura is located between $40^{\circ} 50^{\prime}$ and $41^{\circ} 45^{\prime}$ South Latitude and $66^{\circ}$ and $68^{\circ}$ West Longitude, in the Rio Negro Province, Argentina, approximately 60 miles from the Atlantic coast (Fig. 1). Like the most characteristic Patagonian landscapes, the eroded blackish fields of basaltic rocks form a tabulated plateau that spreads for almost 15,000 square $\mathrm{km}$ at an average altitude of $1300-1400 \mathrm{~m}$. In the southeastern corner of the meseta some irregular small chains of broken summits, often at an altitude of $2000 \mathrm{~m}$, stress the volcanic features of the uplift and.indicate morphological centers of past effusive activity (Fig. 2).

The geological history of the Somuncura region can be traced because the strong Paleozoic deposits accumulated on the granitic shield folded and metamorphosed, and were intrúded by 


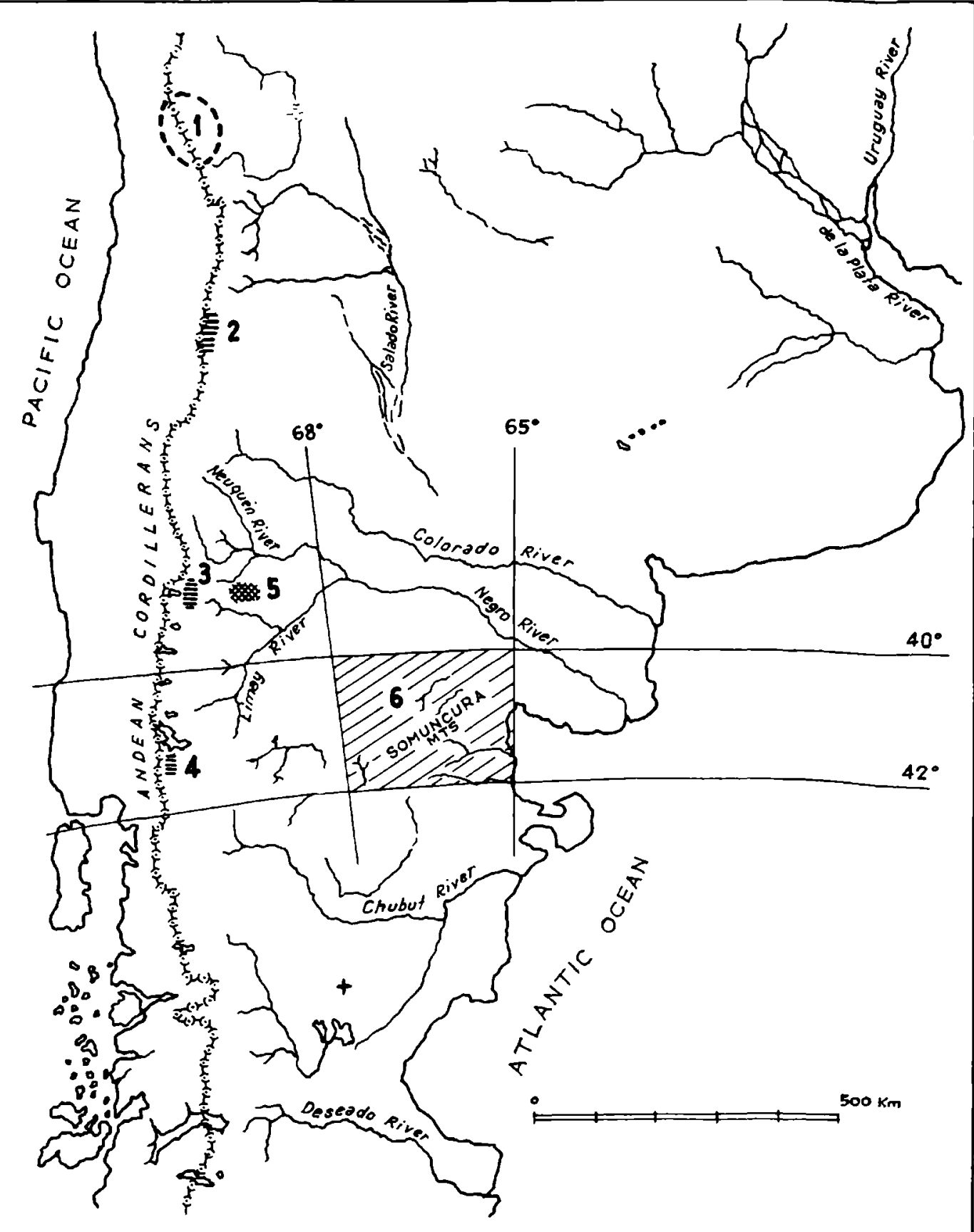

FIGURE 1. General distribution of Telmatobiid frogs south of $33^{\circ}$ South Latitude. Range of Telmatobius montanus: 1) according to Philippi (1902) and Müller (1938); 2) Pehuenche Valley; 3) Lonco Luan plateau: 4) slopes of Tronador Mts. Range of Telmatobius praebasa/ticus and Telmatobius patagonicus; 5) volcanic plateau west of Zapala, Neuquen. Range of telmatobiid frogs from Somuncura basaltic plateau: 6) extraAndean area corresponding to the maps of Fig. 2(A and B). + : Oligocene fauna of Scarritt Pocket (Chubut). 


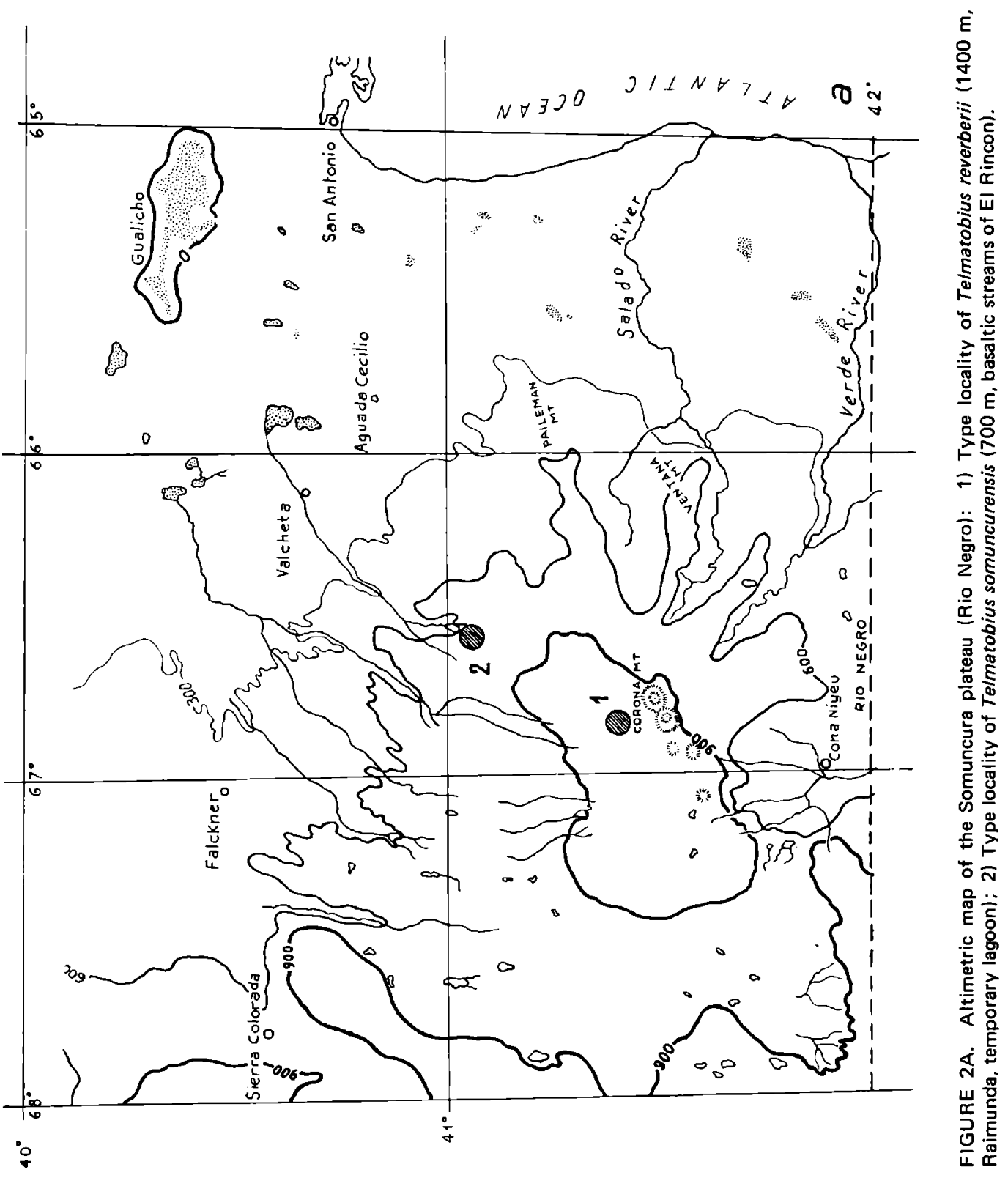




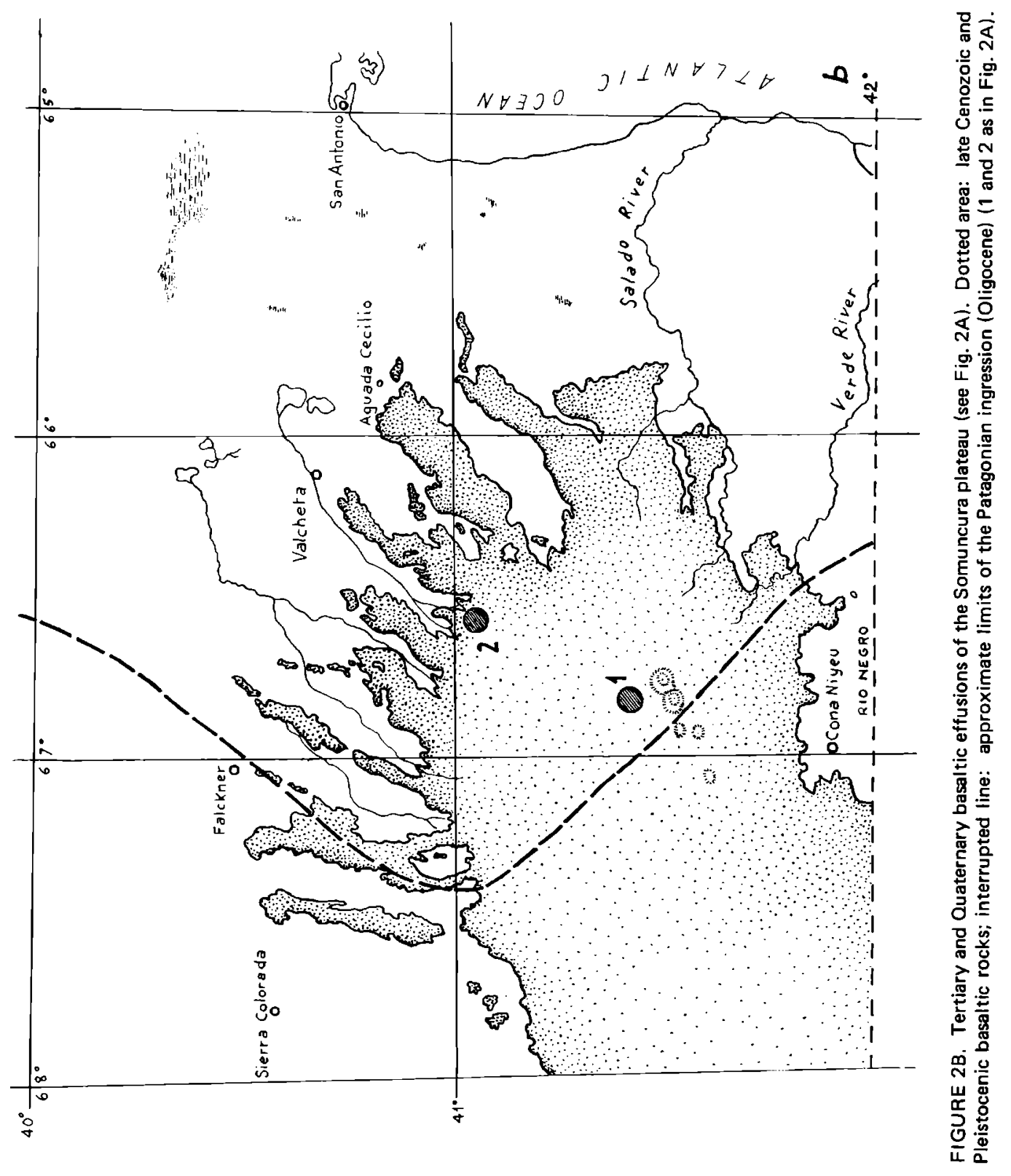


vulcanites in pre-Triassic and Triassic times, and later by discontinuous but rampant Jurassic volcanic activity. During the Cretaceous and Eocene, part of the ancient nesocratonic Patagonian massif (Harrington, 1962) underwent severe erosion and continental accumulation (dinosaur remains). Even though the ingression of the Upper Cretareous seas flooded the subnegative areas between the Deseado, Patagonian and Pampean massifs, the waters did not reach the interior of the Somuncura region. In the Tertiary the southern Middle Oligocene sea transgressed widely on the borders of these undulated lands. Their so-called Patagonian sediments were soon modeled by deep erosion valleys but filled by the powerful extrusions of the Miocene volcanic activity. From Lower Miocene to Pliocene and Quaternary the effusive series rebuilt the Patagonian landscape, and the erosion reversed in many cases its primitive Oligo-Miocene relief. Further uplift of the Andean Cordilleras and the last major tecton ic events at the close of the Pliocene, joined with the Glacial Age and the continental climatic changes, impressed on the Meseta of Somuncura and neighboring territories their present geographic and biocenotic features. All available evidence suggests that no glacial traces are recognizable on the Meseta and its slopes (Methol, 1967; Reverberi, unpublished data). Moreover the physiognomy of this Patagonian territory as a very conservative, ancient emerging area, may be stressed both by its geological evolution and by the main lines of its present biogeographic isolation. This is emphasized by endemism of its telmatobiid fauna. My discovery of the endemic species of telmatobiid frogs of Somuncura points out the striking disjunctive distribution of these anurans (Fig. 1), which were previously considered specialized and localized leptodactylid stock from the Andean belt.

Erroneously included in the phytogeographic Province of the "Monte," or Creosote Bush range (Larrea associations), the Meseta of Somuncura revealed its peculiar biocenotic physiognomy during our field work (1967-68). Over $900 \mathrm{~m}$, it is a true "peninsula" of Patagonian steppes and shrubs, of general southwest-northeast trend. It intrudes in the ecotonal fringe between 500 and $900 \mathrm{~m}$ thus facing the southernmost front of the true Creosote Bush formation. Climbing southwestwards from the salt flats of "Gualicho" to the slopes of volcanic lavas of the Somuncura massif, we cross the alophilous bush zone of Atriplex, Larrea, Prosopis and Condalia shrubs up to about $500 \mathrm{~m}$. Between about $500-900 \mathrm{~m}$ is an ecotonal association with Mulinum, Nassaubia, Chuquiraga avellanedae, Grindellia or Prosopis patagonica as Patagonian elements, and Larrea nitida, Prosopidastrum, Prosopis flexuosa, Condalia and other characteristic plants from the Central or "Monte" Province. Above $900 \mathrm{~m}$, spreading on the open, somewhat undulating landscape of the Meseta, a steppic cover of grass (Stipa, Poa or Festuca) is present, alternating with typical representatives of the environments of the southern Patagonian Province, such as Verbena, Ephedra, Chuquiraga aurea or Mulinum associations (Ruiz Leal, personal communication).

Regional climatic traits are in agreement with the present ecological equilibrium. The average monthly temperature oscillates between $10^{\circ}$ and $16^{\circ} \mathrm{C}$ from November to March, with its maximum in January. They fall between $1^{\circ}$ and $6^{\circ} \mathrm{C}$ from April to October, with a minimum in June-July. Minimum temperatures are very low in winter, often $-25^{\circ} \mathrm{C}$, but temperatures of $4^{\circ}$ or $5^{\circ} \mathrm{C}$ are also very common in summer. Rainfall is scarce in all the coastal district of Rio Negro: $140 \mathrm{~mm}$ per year, distributed irregularly, with frost, snow and hail forming most of the winter's precipitation. During spring and summer rainfall occurs without any apparent seasonal pattern. Rain storms may provoke sudden floods, localized in very limited areas of the Meseta.

The geological and lithological structure and climate of the Somuncura plateau determine its hydrological character, which is a very important factor for the plant and animal life. Three different ecological zones may be mentioned. The first is not fully explored but belongs to the highest summits and southern volcanic cones, snow-covered in winter, some rising above $1500 \mathrm{~m}$ (Cerro Corona, Peñasco Condores). A second hydrological zone of the open steppic uplands (1200-1400 m) corresponds to the scattered volcanic fields of the different effusive series. The great permeability of the basaltic rocks is a strong natural factor against permanent storage of superficial waters. Continuous filtering is the rule; some circular ground depressions surrounded by basaltic cliffs provide a peculiar system of flat, seasonal lagoons. Such temporary lagoons, spreading at distances of 3 $10 \mathrm{~km}$, are very shallow $(1.50 \mathrm{~m})$ and their muddy bottom of clay-degraded basalts probably rests on the lids of old volcanic chimneys closed long ago (Figs. 3-4). The shallow waters of the lagoons, many of which have been carefully studied (Laguna Raimunda, Laguna Chara, Laguna Miñuelo, 

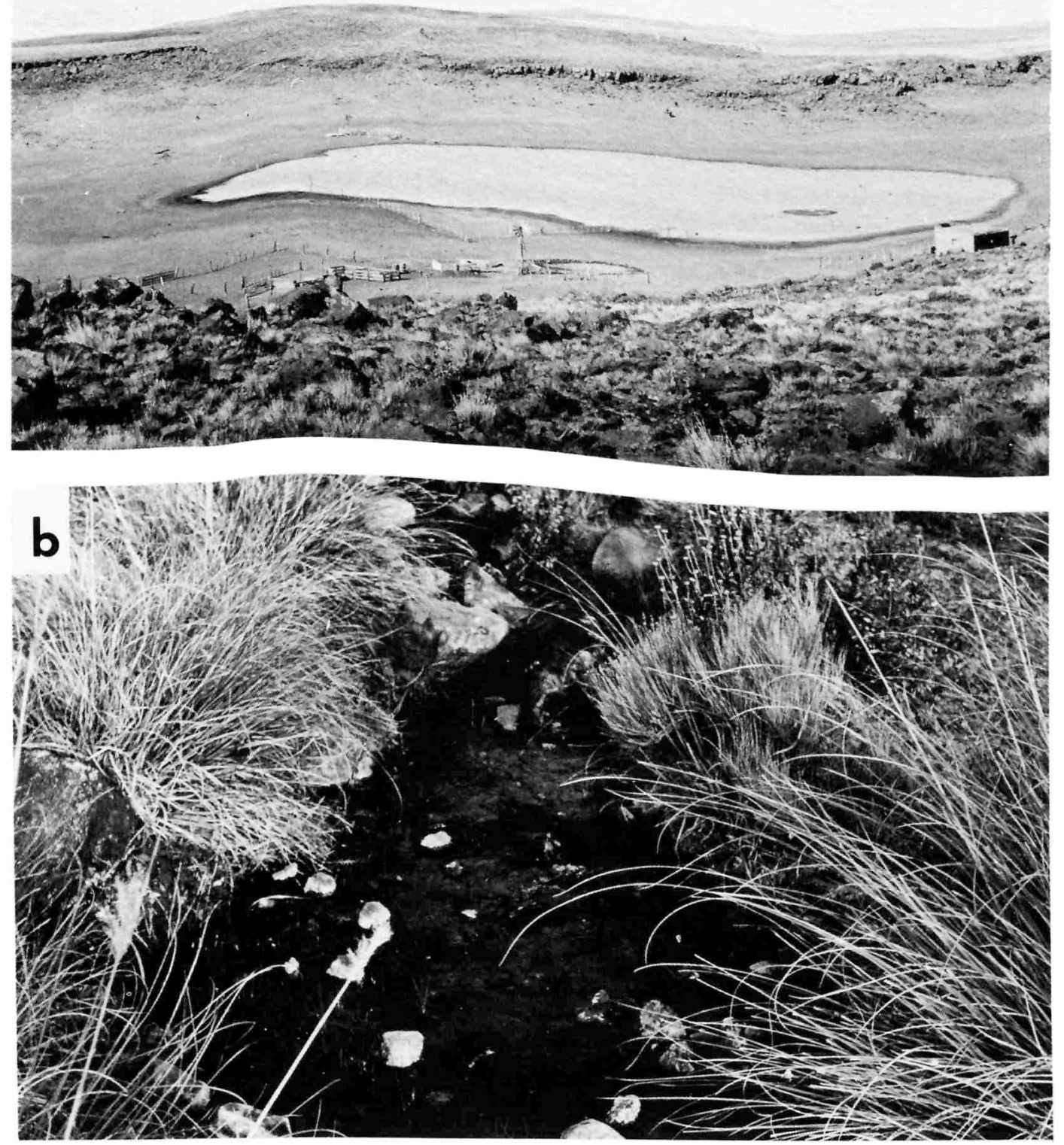

FIGURE 3. a. Laguna Raimunda, $1400 \mathrm{~m}$, Meseta of Somuncura, Rio Negro, Argentina. Type locality of Te/matobius reverberii. b. Rocky stream of El Rincon, northern basaltic slopes of the Somuncura plateau, $700 \mathrm{~m}$. Type locality of Telmatobius somuncurensis. 
a
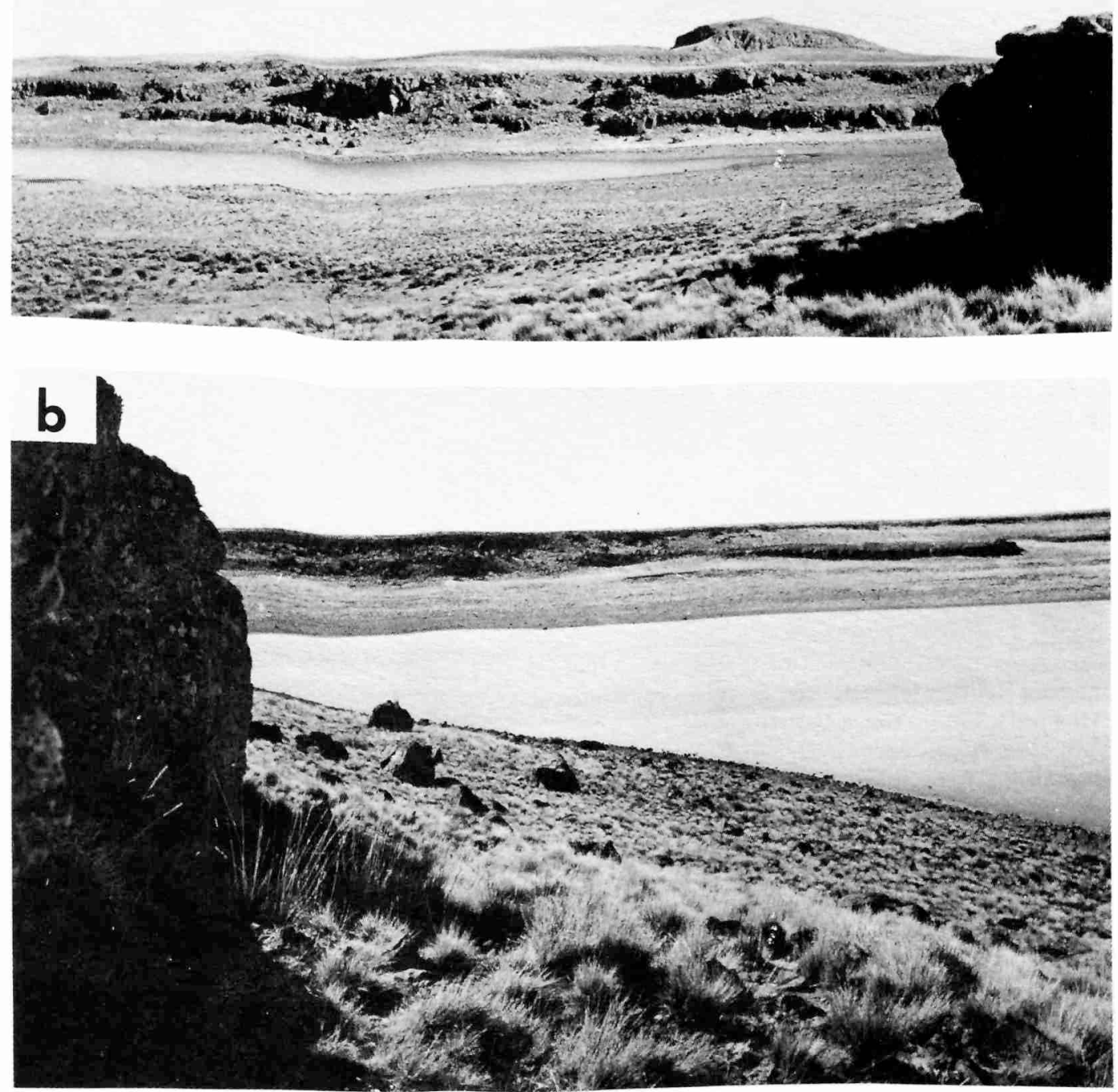

FIGURE 4. a. Basaltic landscape surrounding the Laguna Chara pond. Meseta of Somuncura, $1400 \mathrm{~m}$; b. Laguna Chara, Meseta of Somuncura, $1400 \mathrm{~m}$. 
Laguna Paraguay Grande), are very rich in suspended clay and organic remains, but their salt content is very poor (78-309 $\mathrm{mg} / \mathrm{l})$. Despite the absence of aquatic vegetation plankton is abundant; various species of copepods, ostracods, Branchinecta, and cladocera are present in every month.

A third lower zone $(900$ to $500 \mathrm{~m})$ can be well established in the ecotonal steep slopes. The basaltic filtered waters flow from the highlands in narrow valleys, as permanent or temporary stony streams (Fig. 3b). Sometimes the drainage produces brooks such as the Valcheta River which are quickly dried by the arid northern borders of the Meseta. Environmental conditions of the lower hydrological level are very different from the above mentioned ecological niches, both the temporary lagoons in the arid uplands and the highest volcanic summits. A dense association of Cortaderia speciosa, Agrostis, Cynodon, Samolus and ferns surrounds the rocky streams. Colonies of Mimulus luteus, Azolla and moss float in the clean flows; Nostoc and calcareous algae cover the stones. A number of little amphipods (Talitridae) are abundant in the submerged moss; Oligochaeta, planarians, Hemiptera, and gastropods colonize the bottom.

The exploration of the extra-Andean areas of Patagonia has been our main objective since 1965, after the discovery of representative species of telmatobiid frogs in Neuquen (Gallardo, 1962; Cei \& Roig, 1966). Our explorations from Rio Negro Valley to Southern Santa Cruz, between 1965 and 1967, were partially unsuccessful, obtaining only the widespread Pleurodema bufonina during numerous trips. In December, 1967, during investigation of the Patagonian lands above $42^{\circ}$ South Latitude, a new species of telmatobiid frog was discovered in the crater hollows and clay lagoons of the open uplands of Somuncura $(1400 \mathrm{~m})$. This peculiar environment yielded adults and a great number of tadpoles. Adults, tadpoles, and metamorphosing specimens were also collected there in April, 1968. During additional collecting a second new species of Te/matobius was located in a very different biotope at the lower level of the Meseta, under stones in the rocky streams of the narrow valleys (locality of EI Rincon, $700 \mathrm{~m}$ ). The upper forbidding level of the harsh volcanic cones of Cerro Corona and Cerro Condores has not been fully studied.

The new species which shall be described herein are named Telmatobius reverberii in honor of Dr. Oscar Reverberi, who studied the geology of the region during the last two years (1966-67) and gave me the most valuable cooperation; and Telmatobius somuncurensis, in reference to the geographic endemism.

\section{DESCRIPTION OF THE NEW SPECIES OF TELMATOBIID FROGS FROM THE SOMUNCURA PLATEAU}

\section{Telmatobius reverberii new species}

Holotype:-IBM-UNC, No. 1980/1: a male specimen from Laguna Minuelo, $3 \mathrm{~km}$ north of Laguna Raimunda, Meseta of Somuncura, Rio Negro, Patagonia, Argentina (1400 m), collected 10 April 1968 by the author (Fig. 5a).

Allotype:-IBM-UNC, No. 1981/1: a female from Laguna Raimunda, Meseta of Somuncura, Rio Negro, Patagonia, Argentina $(1400 \mathrm{~m})$, collected 19 December 1967 by the author (Fig. $5 \mathrm{~b})$.

Paratypes:-IBM-UNC, No. 1980/2-3-4-5: four male specimens from Laguna Miñuelo, Meseta of Somuncura, 10 April 1968; IBM-UNC, No. 1981/2: a female, Laguna Raimunda, Meseta of Somuncura, 19 December 1967. Collected by the author.

Diagnosis:-A stout medium-sized frog belonging to the telmatobiid stock and related to the genus Telmatobius, characterized by a Pleurodema-like aspect and almost terrestrial habits, differing from other known members of the genus by the structure and color-pattern of the skin.

Description of Holotype:-Adult male having snout-vent length of $38.0 \mathrm{~mm}$; head length $12.8 \mathrm{~mm}$; head length/snout-vent length 33.6 percent; head width $14.3 \mathrm{~mm}$; head width/snout-vent length 37.6 percent; femur length $17.0 \mathrm{~mm}$; tibia length $17.0 \mathrm{~mm}$; tibia length/snout-vent length 44.7 percent; foot length (from inner metatarsal tubercle to tip of longest toe) $16.8 \mathrm{~mm}$; arm (from axilla to tip of longest finger) $23.9 \mathrm{~mm}$; diameter of eye $4.0 \mathrm{~mm}$. Snout in lateral profile almost square; in dorsal profile obtusely rounded but with protruding noses; canthus evident; loreal region concave; top of head gently declivous; lips rounded and thick; nostril very protuberant; internarial 

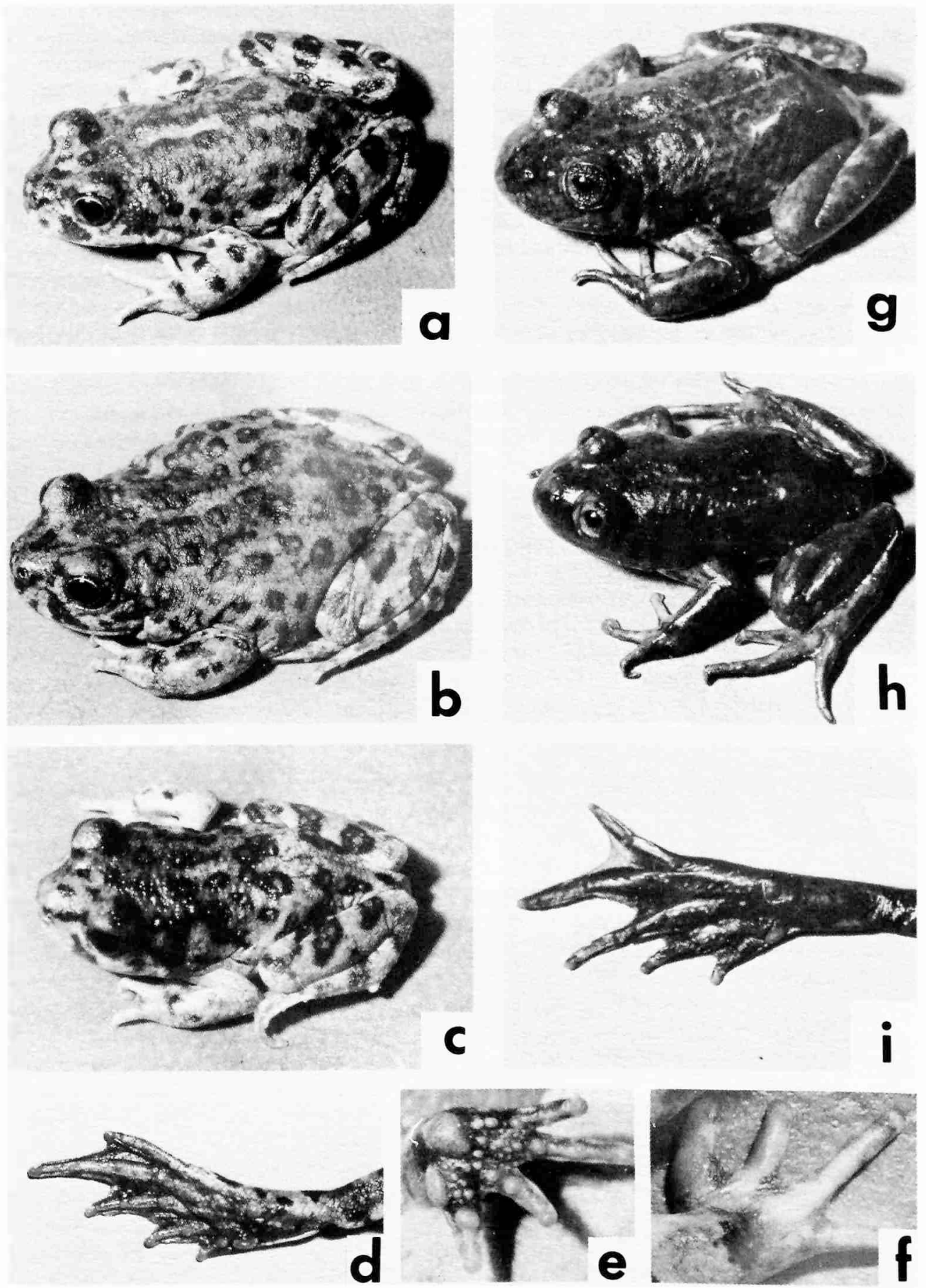

FIGURE 5. a. Te/matobius reverberii, male, holotype; b. T. reverberii, female, allotype; c. T. reverberii, young specimen; d. Foot, inner surface and metatarsal tubercles; e. Hand, inner surface and metacarpal tubercles; f. Thumb pads; g. Telmatobius somuncurensis, holotype; h. T. somuncurensis, paratype (No. 1982/2); i. Foot, inner surface and metatarsal tubercles. (All slightly enlarged.) 
distance $3.8 \mathrm{~mm}$; interorbital distance $(4.3 \mathrm{~mm})$ slightly narrower than width of eyelid $(5.0 \mathrm{~mm})$. A strong dermal fold from posterior corner of eye to insertion of forelimb, covering the tympanic region; tympanum not evident, hidden by the dermal fold; forearm slender, slightly stronger than in the female; few low smooth tubercles on ventrolateral surface of forearm; pollex and second finger with nuptial pads; second and fourth fingers equal in length; cutaneous border between the fingers; subarticular tubercles strong, also present on the surface of the palm; inner metacarpal tubercle strong, oval-shaped; outer metacarpal tubercle, rounded, very enlarged (Fig. $5 \mathrm{e}-\mathrm{f}$ ). Heels do not overlap when hind limb adpressed, tibio-tarsal articulation reaches the eye; strong tarsal fold; inner metatarsal tubercle moderate, paddle-shaped and pronounced (Fig. 5d); outer metatarsal tubercle small and conical; subarticular tubercles conical and prominent; length of digits from shortest to longest 1-2-5-3-4; toes webbed; fourth toe about one-half webbed but with broad cutaneous border to the tip; two rows of low rounded tubercles on the lower tarsal surface. Skin of dorsum, upper surface of forearms and legs sharply granular with rounded flat glandular warts, encircled by dark pigmentary areas; that of throat and belly smooth; ventral surfaces of thighs granular. A well distinguished discoidal fold on the belly. Tongue cordiform, free posteriorly; premaxillary-maxillary teeth strong; vomerine teeth 1-3 in two small prominent patches between and on the median line of the narrow circular choanae. Pectoral girdle as shown in Fig. 6a.
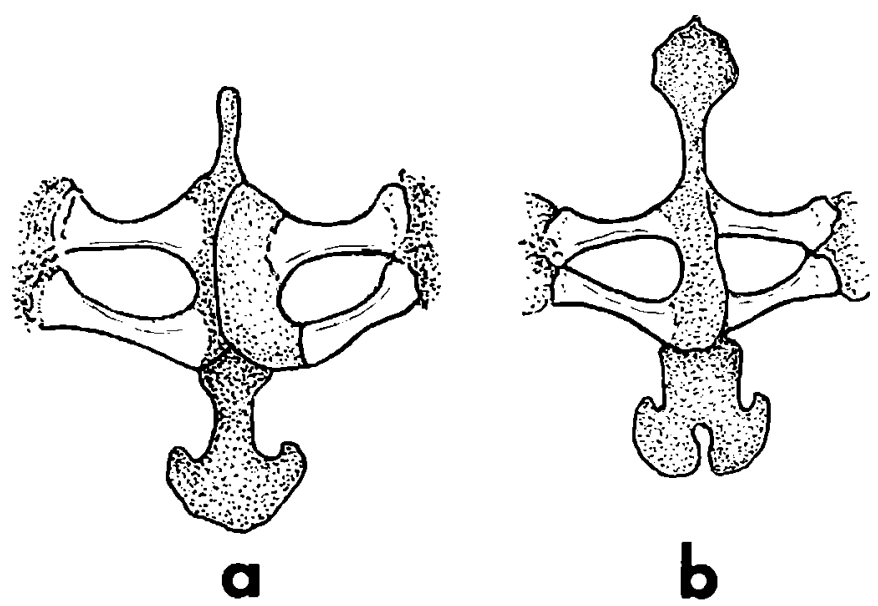

FIGURE 6. Pectoral girdle of: a. Telmatobius reverberii; b. Telmatobius somuncurensis (enlarged).

Color (in alcohol): Gray yellowish on dorsal surface of head, body and legs; round purplish warts surrounded by dark clear-cut irregular spots on the head, dorsum and forearms; an enlarged creamish interscapular spot; dorsal surface of thighs, tibiae and tarsi with dark brown transverse bars; belly whitish with diminutive almost invisible pigmentary blotches. Color (in life): Bright yellowish above, with yellow purple flat warts surrounded by dark regular spots and a light enlarged interscapular stain; dark black bands on the upper surface of the legs; ventral surface whitish, rose-colored on the lower surface of the thighs; minute ventral pigmentation indistinguishable. The allotype agrees well with the holotype in morphological characters; the body is somewhat stouter; dorsal color less yellowish in the female specimens than in the male. Measurements of the allotype are: snout-vent $38 \mathrm{~mm}$; head length $12.3 \mathrm{~mm}$; head width $13.6 \mathrm{~mm}$; femur length $16.5 \mathrm{~mm}$; tibia length $16.5 \mathrm{~mm}$; foot length $16.0 \mathrm{~mm}$; arm $20.5 \mathrm{~mm}$; diameter of eye $4.4 \mathrm{~mm}$. Thus females have shorter legs and arms than the males.

Variation:-Four adult males are available: their snout-vent lengths are $\mathbf{3 5 . 0 - 3 7 . 5 ~ m m ~ ( a v e r - ~}$ age $36.6 \mathrm{~mm}$ ). The head length/snout-vent ratio is 32.0-34.2 (average 32.8); the head width/snoutvent ratio is $37.0-37.3$ (average 37.2 ); the tibia length/snout-vent ratio is $42.6-45.0$ (average 43.7). Variation in color pattern is slight. Measurements of the female paratype are: snout-vent $36.5 \mathrm{~mm}$; 
head length $12.0 \mathrm{~mm}$; head width $13.8 \mathrm{~mm}$; femur length $17.0 \mathrm{~mm}$; tibia length $16.9 \mathrm{~mm}$; foot length $16.4 \mathrm{~mm}$; arm $22.8 \mathrm{~mm}$; diameter of eye $5.0 \mathrm{~mm}$.

A series of seven dead adult specimens was also found in a deep water pit (or "jaguel" by the local name), near the Raimunda lagoon. Because of poor preservation of the soft bodies they have been used only for osteological study. Their body length is $37-45 \mathrm{~mm}$. A recount of the premaxillary and maxillary teeth of the specimens of this series gives for any lateral row an average of 9 (range 8-10) for the premaxillary, and of 24 (range 19-28) for maxillary teeth.

Tadpoles of Telmatobius reverberii:-The different series of tadpoles referred to are: IBMUNC, No. 1974, 95 larvae, Laguna Raimunda, Somuncura, 1400 m, 19-20 December 1967; IBMUNC, No. 1975, 170 larvae, Laguna Miñuelo, Somuncura, 1400 m, 8 April 1968; IBM-UNC, No. 1976, 11 larvae, Laguna Paraguay Chico, Somuncura, 1400 m, 20 December 1967; IBM-UNC, No. 1977, 15 larvae, Laguna Chara, 1390 m, 8 April 1968.

Diagnosis:-A large-sized telmatobiid-like tadpole, body stout and flattened, caudal muscle well developed; fins rather high, tip of tail rounded, eyes and nostril prominent and dorsal; spiracle sinistral, anus dextral, suctorial mouth and lips laterally folded; very scarce brown pigmentation. belly transparent; maximum observed total length $98 \mathrm{~mm}$.

Description:-Tadpoles belonging to No. 1974 may be divided into four morphological groups. A group 26-42 mm (23 tadpoles); a group $43-55 \mathrm{~mm}$ (32 tadpoles); a group 56-72 $\mathrm{mm}$ (18 tadpoles); and a group $80-98 \mathrm{~mm}$ (22 tadpoles). Tadpoles of the first three groups have buds or small hind limbs, but specimens of the fourth group show well developed hind limbs and emerging forelimbs, being considered nearly metamorphosed tadpoles. On the other hand, larvae $14-18 \mathrm{~mm}$ (belonging to No. 1977) lack any outline of initial hind limbs. The following description is especially based on specimens of the third group of No. 1974 having a body length of $30.0 \mathrm{~mm}$ and a total length of $62.0 \mathrm{~mm}$ (Fig. 7). Length of body and head almost twice the width of body; head not wider than body; body stout and somewhat depressed; ventral profile slightly convex; snout sucker-like, protruding; eyes large, dorsal; interocular distance less than eye's distance from the tip of snout, but narrower than the width of anterior dorsal musculature; nostril evident, pigmented, dorsal and salient; distance between nostrils less than their distance from the eye; interorbital distance about twice the internasal distance; spiracle sinistral, opening ventrolaterally, nearer to ventral base of tail than to tip of snout; spiracular tube about equal to diameter of eye; anal tube dextral, extending above an evident fold in ventral fin. Tail musculature longer than head and body; dorsal and ventral fins well developed, lowest near body, becoming higher posteriorly, as musculature narrows; tip of tail gently rounded; dorsal and ventral fins end at base of tail. Skin almost colorless, transparent; viscera visible; width of mouth greater than orbital distance; lips thickened, protruding, folded laterally; edges bordered by numerous, small regular marginal papillae (Fig. 7c). Mouthparts leptodactylid; tooth rows 2/3; upper rows about equal in length, slightly longer than upper beak; second upper row and first lower row narrowly interrupted; other rows continuous, slightly shorter than second lower row. Horny black beak well developed, sharply serrated.

Color in life: golden-brownish above; abdomen transparent, internal organs readily visible; dorsum scarcely mottled with melanophores and guanophores; caudal musculature golden yellowish; caudal fin transparent, colorless. In formalin, almost colorless, dorsum scattered with minute chromatophores metamerically disposed on dorsal caudal musculature, marking course of lateral segmental blood vessels; belly and fins transparent.

Tadpole Biology:-Free-swimming nongregarious tadpoles, found in great number in the shallow clay-waters of the temporary lagoons. They feed on the very abundant floating copepods and Branchinecta. Residues of green algae and mud are contained in their stomach and long coiled intestine (three times the body length). Omnivorous and limeeating habits may be stressed by the protruding mouth and snout, larger in the more developed larvae than in the younger ones. Thus the $\frac{\text { distance eye-base of tail }}{\text { distance eye-snout }}$ ratios are 2.6-3.0 in the $26-55 \mathrm{~mm}$ tadpoles, but 2.2-2.6 in the 80 . $98 \mathrm{~mm}$ tadpoles. The rate of development is unknown, moreover, the presence of tadpoles of various sizes in the samples collected in December, 1967 and April, 1968, together with recently metamorphosed tadpoles (in Laguna Chara lagoons) suggests almost continuous egg-laying in accordance with climatic stimuli, such as the sudden rainfalls of the arid basaltic uplands, and then probably a 


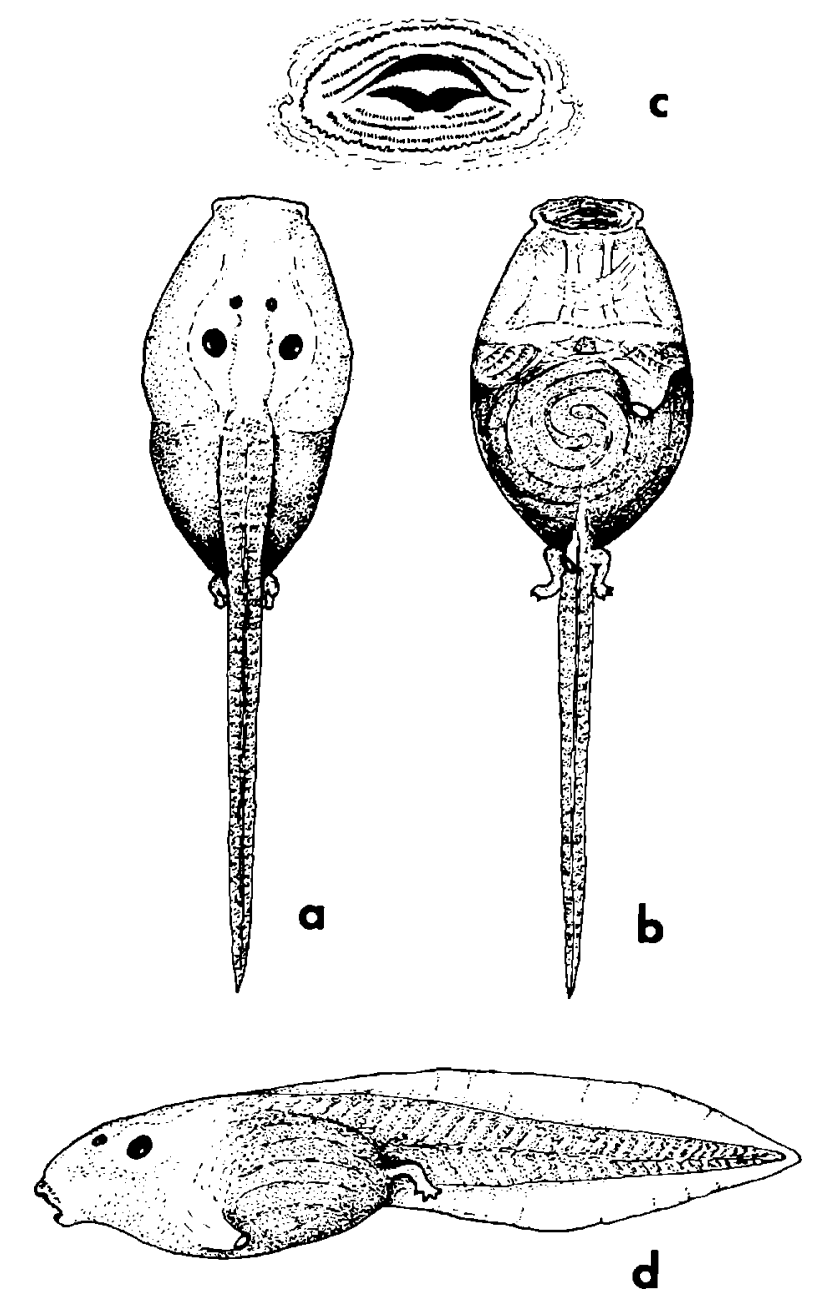

FIGURE 7. Tadpole of Telmatobius reverberii: a. Dorsal view; b. Ventral view; c. Mouth; d. Lateral view; (slightly enlarged).

rather quick larval growth and metamorphosis. Metamorphosing tadpoles have been observed in captivity. They were kept in a field ice-box (at $5-10^{\circ} \mathrm{C}$ ) from 20 December 1967 until they completed a full metamorphosis on 2 January 1968; size of froglets was $14 \mathrm{~mm}$ snout-vent. They are hardy in captivity, feeding easily and voraciously on mealworms, their rapid growth being astonishing, up to a snout-vent length of $30 \mathrm{~mm}$ in 180 days. Color pattern of the metamorphosed and youngest froglets is characterized by a number of brilliant red spots on the dorsum, head and eyelids (Fig. 5c).

Ecological observations:-Terrestrial features of Telmatobius reverberii may be mentioned. The adults are found under stones, in an arid rocky environment, with few scattered clumps of Poa Hordeum, Heliotropium, Juncus and Baccharis tola, sometimes $100 \mathrm{~m}$ from the lagoons. They are poor swimmers and we have found on many occasions dead specimens which had accidentally falle into deep pits in the vicinity of the ponds. These active and resistant frogs jump very easily and feed greedily on insects and mealworms. The stomach content of a male specimen, $37 \mathrm{~mm}$ long, included 1 large tenebrionid beetle, parts of 4 arthropods and plant residues.

The breeding is still unknown, but a continuous cycle may be inferred, probably from late October to April. Also nuptial pads of the males are present in every month; mature testes are 
colorless or brightly pigmented. Mating calls were not heard; however a very evident male warning vibration joined with a release call was observed and recorded (Figs. 8-9). Frequencies of the warning vibration are low: $2.5-3$ pulsations per second. Egg-laying has not been observed. It is assumed that, under the environmental conditions of the volcanic clay lagoons, the egg clutches might be found on the muddy bottom and submerged stones. Diameter of the ripe eggs (in oviduct) is $1.5 \mathrm{~mm}$. Diurnal temperature changes of the Somuncura plateau, of ten swept by violent winds, may well support high adaptiveness of Telmatobius reverberii. Water temperature oscillated, on 19-21 December 1967, from $5^{\circ} \mathrm{C}(9 \mathrm{PM})$ to $6^{\circ} \mathrm{C}(6 \mathrm{AM})$ and $15^{\circ} \mathrm{C}(5 \mathrm{PM})$; air temperature from $7^{\circ} \mathrm{C}$ to $5^{\circ} \mathrm{C}$ and $19^{\circ} \mathrm{C}$, at the same hours. Corresponding temperatures, on 7-9 April 1968, oscillated from $2^{\circ} \mathrm{C}$ to $0^{\circ} \mathrm{C}$ and $13^{\circ} \mathrm{C}$ in the water; from $7^{\circ}$ to $5^{\circ} \mathrm{C}$ and $13^{\circ} \mathrm{C}$ in the air. The borders of he lagoons were frozen in the early morning, during the month of April. A very low thermal

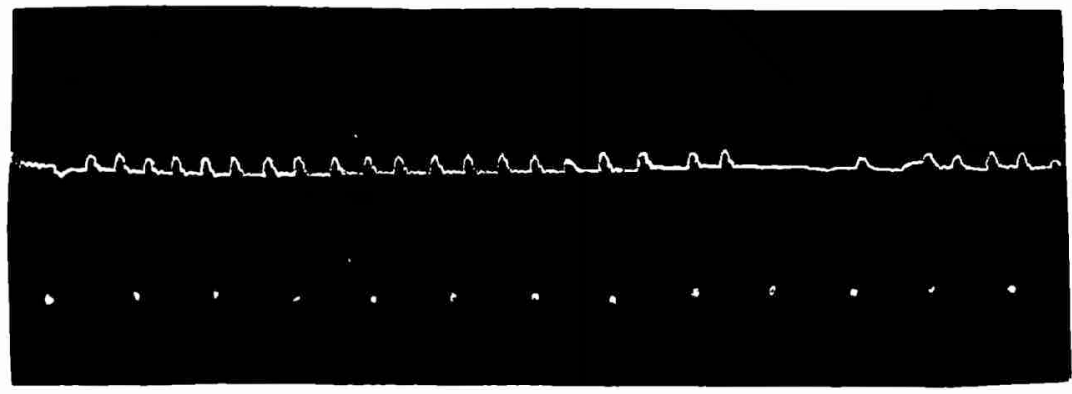

FIGURE 8. Kymographic record of the male release vibration of Telmatobius reverberii $\left(20^{\circ} \mathrm{C} ; 4\right.$ June 1968); scale: $1: 1$ time between points equals $1.0 \mathrm{sec}$.

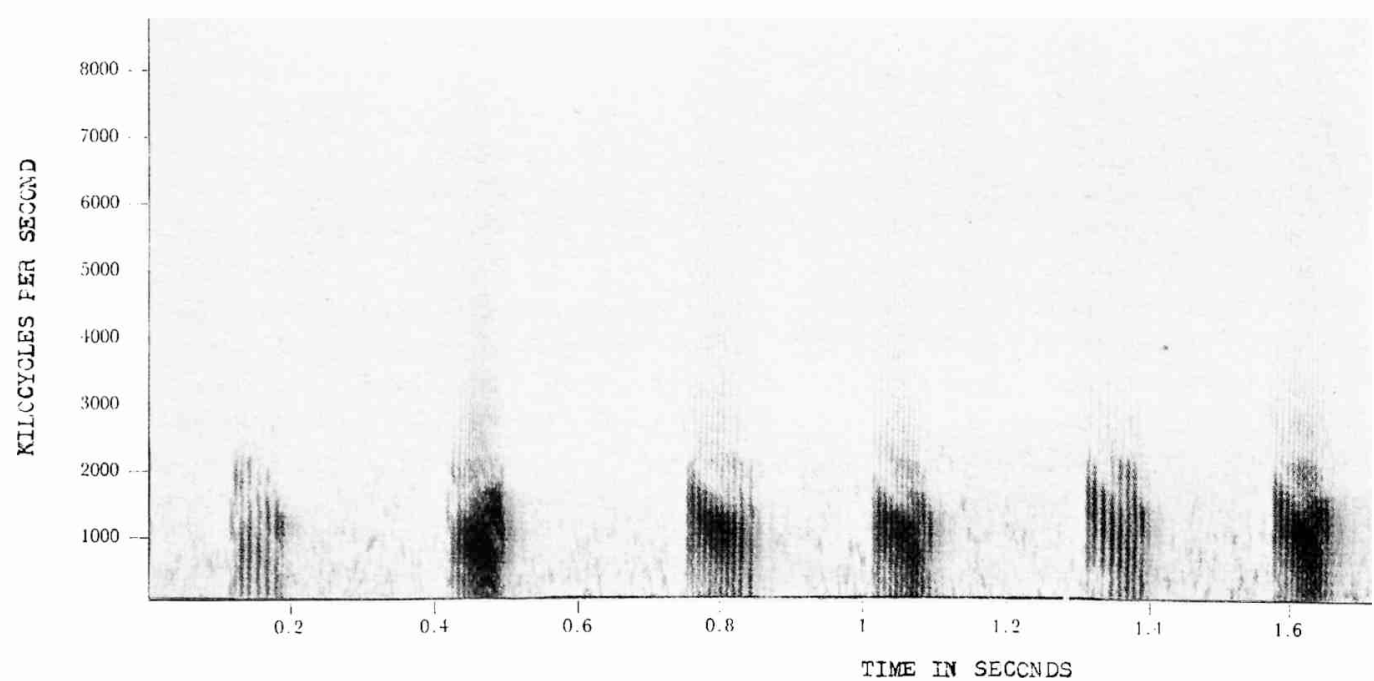

TYPE G/GB gonagram $\theta$ KaY ELECtric CO.

FIGURE 9. Audiospectrograph of the male release call of Telmatobius reverberii (IBM-UNC-SR-F.7). Short rhythmic series of notes, nine to eleven notes per series, repeated at intervals of about 0.2 seconds. Each series has a duration of 0.1 of a second. The dominant lower frequency band falls between 0 and $2300 \mathrm{cps}$. (20 $\mathrm{C}$; 4 June 1968). 
optimum may be assumed for embryonic development, hatching and larval growth. Other seasonal irregularities of the Meseta climate emphasize the specializations of its peculiar telmatobiid form. The clay lagoons were dried since late January; on 3 March 1968 a sudden storm flooded some of them, such as Laguna Raimunda and Laguna Chara, some $3.6 \mathrm{~km}$ away. Other lagoons, such as Miñuelo and Paraguay Grande, were excluded from the flood. In April, Laguna Chara had a crowded population of young tadpoles and a very rich plankton. Sudden breeding activity after the storm, in late March, is highly probable. On the bottom of the Minuelo Pond some water pits, 5-6 m deep, remained during the summer, and a dense population of adults, metamorphosed froglets and tadpoles at various stages were able to exist there during unfavorable environmental conditions. The morphology of this species, in particular its strong paddle-shaped metatarsal tubercle (Fig. 5d), could indicate fossorial habits. The ecology of this form during the prolonged hard winter season is unknown, but it is probable that it is a period of starvation, and that the frozen ground protects adults and nearly metamorphosed froglets until the rising temperatures and the rains of the late spring.

\section{Telmatobius somuncurensis new species}

Holotype:-IBM-UNC, No. 1982/1: a female from El Rincon stream, $60 \mathrm{~km}$ SSW from Valcheta, Rio Negro, Argentina, on the basaltic slopes of Somuncura plateau (700 m), collected 11 April 1968 by the author (Fig. $5 \mathrm{~g}$ ).

Allotype:-Males unknown.

Paratypes:-IBM-UNC, No. 1982/2-3-4-5, four females from the same locality, collected 11 April 1968 by the author (Fig. 5h).

Diagnosis:-A slender medium-sized Telmatobius, differing from other known members of the genus by the unique structure of the iris, and a characteristic light stripe on the dorsum.

Description of Holotype:-Adult female having snout-vent length of $38.0 \mathrm{~mm}$; head length $12.2 \mathrm{~mm}$; head length/snout-vent length 32.1 percent; head width $11.0 \mathrm{~mm}$; head width/snoutvent 28.9 percent; femur $17.1 \mathrm{~mm}$; tibia length $16.4 \mathrm{~mm}$; tibia length/snout-vent length 43.1 percent; foot length (from inner metatarsal tubercle to tip of largest toe) $20.5 \mathrm{~mm}$; arm (from axilla to tip of largest finger) $24.3 \mathrm{~mm}$; diameter of eye $3.7 \mathrm{~mm}$. Snout in lateral profile gently rounded; in dorsal profile rounded; nose not protruding; canthus slightly evident; loreal region almost flat; top of head slightly declivous; lips rounded; internarial distance $3.0 \mathrm{~mm}$; interorbital distance $(3.0 \mathrm{~mm})$ narrower than width of eyelid $(4.4 \mathrm{~mm})$. A supratympanic dermal fold from posterior corner of eye to insertion of forelimb; tympanum rounded, diameter $2.4 \mathrm{~mm}$; forearm slender; few low tubercles on ventrolateral surface of forearm; second finger shorter than the fourth; fingers free, without cutaneous border; subarticular tubercles conical, low; metacarpal tubercles reduced, the outer almost indistinguishable. Heels do not overlap when hind limbs adpressed; tibio-tarsal articulation reaches the eye; no tarsal fold; inner metatarsal tubercle moderate, conical; outer metatarsal tubercle very reduced; subarticular tubercles small, conical, not prominent; length of digits from shortest to longest: 1-2-5-3-4; toes about one third webbed with broad cutaneous border to the tip (Fig. 5i). Two symmetrical rounded peculiar structures on the center of the upper and lower border of the iris (Fig. 10). Skin of dorsum, belly and ventral surface of thighs smooth; upper surface of cloaca slightly everted (Fig. 11); tongue subcircular, free posteriorly; premaxillary (10) - maxillary (36) teeth strong; vomerine teeth reduced, in two slightly prominent patches between and on the median line of the circular choanae. Pectoral girdle as shown in Fig. $6 \mathrm{~b}$.

Color (in alcohol): Yellowish-brownish on dorsal surface of head, body and legs; irregular dorsal dark spots, reticulated on the sides and the upper posterior surface of thighs, tibiae and tarsi; belly yellowish, with faint reticulated gray spots. Color (in life): Bright yellowish-brown above, with small irregular dark spots and a light yellowish medial stripe on the anterior part of dorsum; belly purplish-yellow with dark gray reticulated spots; lower surface of the thighs purplish-rose, with faint reticulated gray spots; iris golden, with dark upper and lower central protruding structures (menisci). 

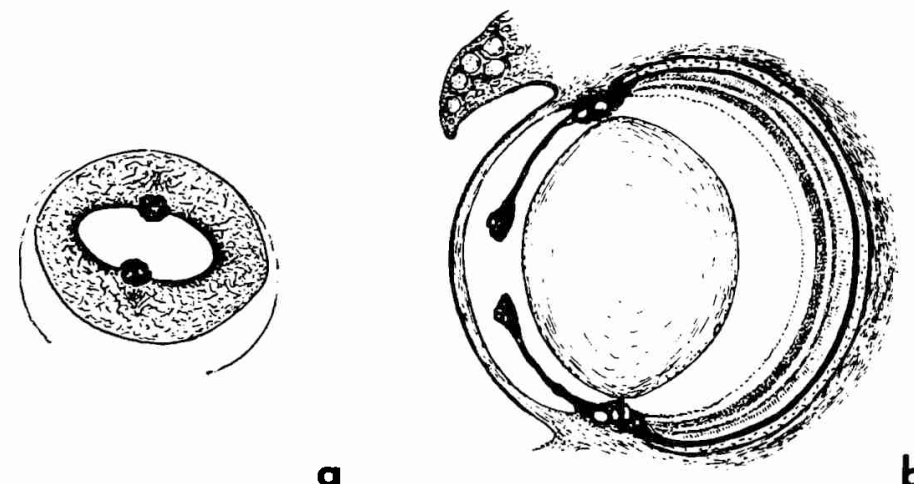

FIGURE 10. a. Iris of Telmatobius somuncurensis. The rounded structures on the upper and lower pupillar borders are indicated. b. Medial section of the eye of Telmatobius somuncurensis, through the central zone of the iris. (Enlarged.)
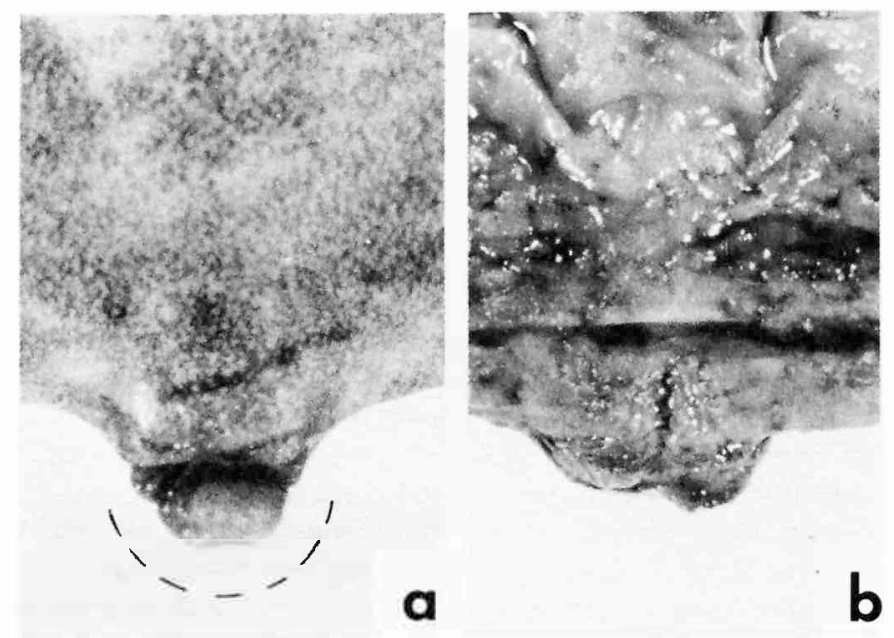

FIGURE 11. a. Everted cloaca of a female specimen of Te/matobius somuncurensis (IBM-UNC-1982/4). The broken line indicates the natural position reached in life by the erectile organ, (folded in the fixed specimen). b. Cloaca of a female specimen of Telmatobius patagonicus (IBM-UNC-1282/33). No everted cloaca is present. (Enlarged.)

Variation:-Four adult females are available; their snout-vent lengths are $31.43 .5 \mathrm{~mm}$ (average 37.8). The head length/snout-vent ratio is 31.2-35.7 percent (average 33.8); the head width/ snout-vent ratio is 28.7-34.1 percent (average 31.5); the tibia length/snout-vent ratio is $42.5-43.8$ percent (average 43.2). Variation in color pattern is small.

Ecological remarks:- Like most Telmatobius, aquatic habits of Telmatobius somuncurensis are stressed both by morphological and ecological trends. As typical inhabitants of permanent water, they live under stones in the current of the streams, or submerged in the soft masses of floating mosses. In spite of careful search no tadpoles or metamorphosing specimens have been 
found during April 1968. It is thus difficult to establish the breeding and egg-laying periods of this species, but they probably occur in the late spring or early summer. Telmatobius somuncurensis is a hardy captive and feeds readily on mealworms and small arthropods. All specimens examined were parasited by Hydracarina, with incapsulated Leptus under the skin.

\section{DISCUSSION}

The geographic isolation and the high ecological specialization of the telmatobiid frogs from the Somuncura Plateau have been emphasized. This peculiar volcanic uplift is located at some $250 \mathrm{~km}$ from the nearest biocenotic Andean environment, such as the Nahuel Huapi Lake and the antartandic forest. It is widely surrounded by a very arid and alophilous landscape; northeastwards by the great depression of Gualicho; and on the northern borders by the very low salt-containing communities of Heterostachis and Atriplex. The desert ravines of the basaltic Tertiary extrusions, protruding south and westwards of the Somuncura uplands, have scattered populations of the Patagonian frog Pleurodema bufonina (Bell); no other anurans were found there during our repeated searches. On the eastern side, in the ecotonal zone facing the Atlantic shores, a transitional anuran fauna may be observed in the same creeks: Pleurodema bufonina, Odontophrynus occidentalis (Berg) and Bufo arenarum Hensel. This Late Pampean toad can also reach the slopes of the Meseta, up to an altitude of $700 \mathrm{~m}$, as in the streams of Rincon, where it seems to live in an ecological niche similar to that of Telmatobius somuncurensis. Pleurodema bufonina is also scattered in the uplands where there are evident Patagonian formations; the highest locality of $P$. bufonina south of Somuncura Mountains is at present Cona Niyeu, $540-600 \mathrm{~m}$.

Other isolated, probably relict populations of animals are found in the Meseta of Somuncura. The biota of the uplands and the steep valleys includes only a reduced number of mammals, such as small rodents (Lagidium viscacha somuncurensis, Ctenomys, etc.), dasypodids and carnivora (abundant Dusicyon culpaeus), a number of aquatic birds (Ch/oephaga or Phoenicopterus ruber), and lizards (Liolaemus, Diplolaemus and Phymatura). Many of the lizards are endemics. No snakes have been seen over $1400 \mathrm{~m}$. Small characid fishes (Gymnocharacinus bergi) live in the rocky streams of EI Rincon. Tenebrionid beetles, ants and wingless Orthoptera are frequent; spiders and scorpions have been found under stones.

Undoubted telmatobiid relationships of our new extra-Andean forms are indicated by several morphological characters or, as in the case of somuncurensis, by ecological preferences and biology. The curious anatomical features of the iris of Telmatobius somuncurensis must also be pointed out. The double and quite symmetrical discoidal structure on the upper and lower pupillar border of this species is similar to the upper "meniscus" of the Brasilian frogs Cyclorhamphus, reported by Lutz (1929) and Bokermann (1951) but inexplicably disregarded by Cochran (1955). This morphological and likely physiological affinity between the localized Patagonian species and the eastBrazilian genus is a very suggestive one because of the past taxonomic confusion between Telmatobius and Cyclorhamphus (lliodiscus and Grypiscus are synonyms). The ecological and phyletic relationships of both "telmatobiid" stocks are unquestionable. The lack of male somuncurensis prevents me, unfortunately, from analyzing additional common characters, such as the inguinal glandular discs. The following species of Telmatobius have been carefully studied: albiventris, brevipes, crawfordi, culeus, escomeli, hauthali, halli, jelskii, latirostris, marmoratus, montanus, oxycephalus, patagonicus, peruvianus, praebasalticus, reverberii, rimac, simonsi; also Batrachophrynus macrostomus and brachydactylus. None has the structure of the iris reported here for Telmatobius somuncurensis. The curious tendency of the females of this species to have a somewhat everted cloaca should be further investigated in the males.

A comparative study of Telmatobius reverberii may show enough peculiarities as to question the relationship of this frog to any recognized species of Te/matobius (Vellard, 1951). Its uncommon life history on the arid basaltic plateau, along with the exceptional hydrological system of the volcanic clay-lagoons, may reflect some of its specialized characters, such as the strong development of the metatarsal paddle-like tubercles, the hidden tympanum, the granular structures of the skin, perhaps the protruding nose and stout body, which may be convergent with the leptodactylid stock Pleurodema. The well-marked discoidal fold on the belly of Telmatobius reverberii 
suggests that the affinities of our Patagonian frog lie with the forms of this genus, or to the related genera Physalaemus and Leptodactylus.

Telmatobiid relationships are undoubtedly indicated by osteological characters such as the evident interparietal "fontanelle," the structure of pectoral girdle, toes and feet, and above all by the general organization and appearance of the giant tadpoles. They are quite similar to the largesized tadpoles of Telmatobius patagonicus (Gallardo), from which they differ only by some meristic parameters of the eyes, nostrils, and snout (Cei, 1965). The dorsal color-pattern of Telmatobius reverberii is suggestive of another recently described smaller species of semi-terrestrial telmatobiid frog, Telmatobius praebasalticus Cei \& Roig (1968) from the extra-Andean volcanic uplands west of Zapala, Neuquen. The red warts encircled by pigment spots in the young and adult specimens of Telmatobius reverberii are unusual characters for any described species of Telmatobius, but they have been reported for praebasalticus, in which a slightly recognizable ventral discoidal fold may be observed.

The semi-terrestrial frog Telmatobius praebasalticus is sympatric with Telmatobius patagonicus, which is a very specialized aquatic inhabitant of another peculiar hydrological system of endorreic lagoons (Cei \& Roig, 1966). Analogies or parallelisms may be emphasized between the biocenotic conditions of Somuncura and the system of shallow lagoons west of Zapala, Neuquen, $400 \mathrm{~km}$ northwestwards. Such a system of shallow lagoons also lies in a basaltic rocky upland, $1300 \mathrm{~m}$, belonging to the same late Tertiary and Quaternary volcanic activity which rebuilt the ancient "praebasaltic" landscape and drainage of the region (Groeber, 1929). The relict woods of Araucaria araucana, adjacent to the district of the Neuquen ponds, are remnants of the ancient Cenozoic associations. Of course the biocenotic characteristics of these two isolated and separated Patagonian networks of ponds are not identical. The bare bottom and the floating plankton of the Somuncura waters differ strongly from the thick but uniform redd ish vegetation of the volcanic basins of Neuquen, crowded by Myriophyllum brasiliense, M. elatinoides, or Zanichellia palustris and filled by a dense crawling population of amphipods (Hyalella) and leeches. In spite of the evident regional differences, a convergence during the ancestral processes of adaptive speciation is suggested. Morphological and ecological similarities between the allopatric Telmatobius reverberii and Telmatobius praebasa/ticus may suggest some major line of telmatobiid-like descent, under the climatic selective shift which took place at the close of the late Tertiary. When an adequate biological and taxonomic revision of Telmatobiinae is undertaken, it should be possible to detect and define species-groups. A natural approach to the terrestrial forms, reverberii and praebasalticus, might be to include them under a "Somuncuraia" section, as opposed to a "Telmatobius" section and others as necessary.

The early evolutionary history and the present geographical distribution of the Andean and extra-Andean Telmatobiini (Fig. 1) can only be tentatively reconstructed on the basis of the available evidence. My discovery of an isolated Patagonian area of speciation, far away from the Andean Cordilleras and near the Atlantic, suggests a former widespread dispersal of the genus in agreement with the late paleogeographic and paleoclimatic development of the nesocratonic units and pericratonic basins of austral South America. Oligocenic ingressions, mountain uplift and repeated rampant volcanic activity since Miocene time, as well as the progressive increase of continental aridity, may mediate as general isolating factors. It is noteworthy that in the stable emergent land mass of the Patagonian Massif, in which most of the Somuncura plateau is located, the well known Deseadan Oligocene fauna of Scarritt Pockett was found, on the west side of the Sierra Canquel, north of the Colhue Huapi Lake, Chubut, $300 \mathrm{~km}$ southwards from Somuncura Mountains (Chaffee, 1952). Between the fossil strata of Scarritt Pockett a typical antartandic anuran fauna has been reported, such as Eupsophus and a Calyptocephalella, near the Miocenic Gigantobatrachus parodi Casamiquela from Rio Negro, in the neighborhood of the Meseta of Somuncura. Joined with these antartandic elements some more problematic forms, such as Eophractus and Neoprocoela edentata Schaeffer, were found. The latter was claimed as a "true but primitive leptodactylid" supported by "the general nature of the skull, affinity with the more generalized South American leptodactylids such as Telmatobius or its edentulous derivative, Batrachophrynus." Thus, according to Schaeffer (1949), "the fontanelle of Neoprocoela and of Telmatobius are of about equal size, separating the frontoparietals for most of their length." In spite of other interesting studies made 
to indicate the bufonid nature of Neoprocoela (Tihen, 1962), the problem is unsolved. It stresses the special value of the study of the living and probably relictual telmatobiid frogs from the Somuncura uplands.

\section{ACKNOWLEDGMENTS}

The useful criticism of the geological and botanical material in this paper by Dr. O. Reverberi, Dr. A. Ruiz Leal and Ing. F. A. Roig is acknowledged. The author especially appreciates the capable aid of Dr. A. Barrio, who assisted with the audiospectrographic analysis of the release call. The aid of Ing. L. Nijenshon, who carried out the water analysis of the lagoons, and of Dr. S. R. Olivier who studied preliminarily the plankters, is also acknowledged. The author is indebted finally to Mr. J. Asconape from Valcheta (Rio Negro) for his remarkable help during the field work on the almost impassable uplands of the Meseta of Somuncura.

This project has been supported by the grant No. 2158/a of the Consejo Nacional de Investigaciones Cientificas y Tecnicas, Buenos Aires.

\section{LITERATURE CITED}

Bokermann, W. C. A. 1951. Sinopse das especies brasileiras do genero Cyclorhamphus Tschudi. Argu. Museu Nac., Rio Janeiro, 42: 77-92.

Casamiquela, R. M. 1958. Un anuro gigante del Mioceno de Patagonia. Rev. Ass. Geolog. Arg. 13(3): 171-183.

- 1963. Sobre un par de anuros del Mioceno de Rio Negro (Patagonia) Wawelia gerholdi n. gen. et sp. (Ceratophrydidae) y Gigantobatrachus parodi (Leptodactylidae). Ameghiniana (Rev. Ass. Paleont. Arg.) 3(5): 141-160.

Cei, J. M. 1965. The tadpole of Batrachophrynus patagonicus Gallardo. Herpetologica 20(4): 242-245. and V. G. Roig. 1965. The systematic status and biology of Telmatobius montanus Lataste (Amphibia - Leptodactylidae). Copeia (4): 421-425.

and ㄴ. 1966. Los caracteres biocenoticos de las lagunas basalticas del oeste del Neuquen. Bol. Estudios Geogr. U. N. C. Mendoza 13(51): 182-201.

and 1968. Telmatobiinos de las lagunas basálticas de Neuquén (Anura, Leptodactylidae). Physis 28(75): 265-284.

Chaffee, R. G. 1952. The deseadan vertebrate fauna of the Scarritt Pocket, Patagonia. Bull. Amer. Mus. Nat. Hist., 98(6): 509-562.

Cochran, D. M. 1955. Frogs of southeastern Brasil. United States Natl. Mus. Bull. 206: 1-422.

Gallardo, J. M. 1962. Los géneros Telmatobius y Batrachophrynus en la Argentina (Amphibia - Leptodactylidae). Neotropica, 8(26): 45-58.

Groeber, P. 1929. Líneas fundamentales de la geologia de Neuquén, sur de Mendoza y regiones adyacentes. Publ. Dir. Gen. Min. Geol. Hidrol., Buenos Aires, 58: 1-110.

Harrington, H. J. 1962. Paleogeographic development of South America. Bull. Amer. Ass. Petroleum Geol., 46(10): 1773-1814.

Lutz, A. 1929. Taxonomia e biologia do genero Cyclorhamphus. Mem. Inst. Oswaldo Cruz, 22(1): 5-25.

Methol, E. J. 1967. Rasgos geomorfológicos de la Meseta de Somuncura, Río Negro. Consideraciones acerca de los orígenes de los "pequeños bajos sin salida." Rev. Assoc. Geol. Argentina, 22(4): 295-311.

Müller, L. 1938. Beiträge zur Kenntnis der Herpetofauna Chiles. X. Über ein Exemplar Te/matobius montanus Philippi. Zool. Anz. 121: 313-317.

Philippi, R. A. 1902. Suplemento a los batraquios chilenos descritos en la Historia Fisica y Politica de Chile de don Claudio Gay. Santiago, pp. 1-161.

Schaeffer, B. 1949. Anurans from the Early Tertiary of Patagonia. Bull. Am. Mus. Nat. Hist., 93(2): 47-68.

Tihen, J. A. 1962. A review of New World fossil bufonids. Amer. Midl. Nat., 68: 1-50.

Vellard, J. 1951. Estudios sobre Batracios andinos. I-El grupo Telmatobius y formas afines. Mern. Mus. Hist. Nat. "J. Prado," Lima, 1: 3-89. 